\title{
THE OPTIMAL DOSE OF INTRAPERITONEAL HEAT SHOCK PROTEIN (HSP7O) TO PREVENT DEATH IN SEPSIS MICE MODEL WITH MULTIPLE ORGAN DYSFUNCTION SYNDROME
}

\author{
IGL Sukamto'), Bambang Purwanto'), Ambar Mudigdo3), Suroto4) \\ 1)Doctoral Program in Medicine, Universitas Sebelas Maret \\ 2)Department of Internal Medicine, Dr.Moewardi/ \\ Faculty of Medicine, Universitas Sebelas Maret \\ 3)Department of Anatomic Pathology, Dr.Moewardi/ \\ Faculty of Medicine, Universitas Sebelas Maret \\ 4)Department of Neurology,Dr.Moewardi/ \\ Faculty of Medicine, Universitas Sebelas Maret
}

\begin{abstract}
Background: In theory, heat shock protein (HSP70) can reduce the expression of Cyt. C, Bax, and Caspase 3, in apoptosis ofmultiple organ dysfunction syndrome (MODS), and thereby can prevent death. Previous researchers used $226 \mu \mathrm{g} / \mathrm{KgBW} /$ intraperitoneal (ip) of HSP7O. There is a lack of studies which used the lowest effective dose of HSP7O. This study aimed to determine the lowest effective dose of HSP7O to prevent death in sepsis mice model with MODS. Subjects and Method: This was a randomized control trial conducted at PAU Universitas GadjahMada, Yogyakarta, from April 1 to 21, 2017. The study subjects were Balbs/c strain mice. The drug used to induce death was Lipopolysaccharides (LPS) from SIGMA L2880-10MG Lot \# 025M4040V from Escherichia coli 055:B5 purified by phenol extraction. The drug used to prevent death in this study was Rat Heat Shock Protein (HSP70) Lot\#L16020515. A sample of 25 mice was randomized into 5 groups with each consisting of 5 mice: (1) control group with $\mathrm{NaCl}$; (2) experimental group receiving LPS injection of $0.25 \mathrm{mg} / \mathrm{kgBW} / \mathrm{ip}$; (3) experimental group receiving LPS injection of $0.25 \mathrm{mg} / \mathrm{kgBW} / \mathrm{ip}$ with $\mathrm{HSP} 7 \mathrm{O}$ injection of $100 \mu \mathrm{g} / \mathrm{kgBW} / \mathrm{ip}$; (4) experimental group receiving LPS injection of $0.25 \mathrm{mg} / \mathrm{KgBW} / \mathrm{ip}$ with HSP7O injection of $200 \mu \mathrm{g} / \mathrm{kgBW} / \mathrm{ip}$; and (5) experimental group receiving LPS injection of $0.25 \mathrm{mg} / \mathrm{kgBW} / \mathrm{ip}$ with $\mathrm{HSP} 7 \mathrm{O}$ injection of $300 \mu \mathrm{g} / \mathrm{kgBW} / \mathrm{ip}$. The percent of live mice between groups was compared by chi square.

Results: Three days after intervention, the number of live mice $13(86.7 \%)$ in the experimental group with $\geq 100 \mu \mathrm{g} / \mathrm{kgBW} / \mathrm{ip} \mathrm{HSP70}$ was greater than the number of live mice $2(40 \%)$ in the experimental group with $<100 \mu \mathrm{g} / \mathrm{kgBW} / \mathrm{ip} \mathrm{HSP7O}$, with $\mathrm{p}=0.037$. In addition, all mice receiving $\geq 200 \mu \mathrm{g} / \mathrm{kgBW} / \mathrm{ip} \mathrm{HSP} 7 \mathrm{O}$ in the experimental group were alive three days after intervention.

Conclusion: The lowest effective dose of HSP70 to prevent death in sepsis mice model with MODS is $100 \mu \mathrm{g} / \mathrm{kgBW} / \mathrm{ip}$. All mice are alive three days after receiving $\geq 200 \mu \mathrm{g} / \mathrm{kgBW} / \mathrm{ip} \mathrm{HSP7O}$.
\end{abstract}

Keywords: lipopolysaccharide, heat shock protein, multiple organ dysfunction syndrome, dose

\section{Correspondence:}

IGL Sukamto. Doctoral Program in Medicine, Universitas Sebelas Maret, Jl. Ir. Sutami No. 36 A, 57126, Surakarta, Central Java.

Email: igl.sukamto.span.dr@gmail.com. Mobile: 08122974441.

Mid-International Conference on Public Health, Best Western Premier Hotel, Solo, Indonesia, 18-19 April 2018 | 259 https://doi.org/10.26911/mid.icph.2018.05.21 